\title{
Formation of Frozen Blackcurrant Fruits Quality
}

\author{
N. Osokina ${ }^{1}$, K. Kostetska ${ }^{1 *}$ and H. Gerasymchuk ${ }^{1}$ \\ ${ }^{1}$ Uman National University of Horticulture, Department of Technology of Storage and Processing of \\ Grain, St. Instytutska 1, UA20305 Uman, Ukraine.
}

Authors' contributions

This work was carried out in collaboration among all authors. All authors read and approved the final manuscript.

Article Information

DOI: $10.9734 / A R R B / 2020 / v 35 i 1030295$ Editor(s):

(1) Dr. Paola Angelini, University of Perugia, Italy. Reviewers:

(1) Navneet Kumar, Anand Agricultural University, India. (2) R. K. Patel, ICAR-Indian Grassland and Fodder Research Institute, India. Complete Peer review History: http://www.sdiarticle4.com/review-history/61468

Original Research Article

Received 26 July 2020

Accepted 02 October 2020

Published 30 October 2020

\section{ABSTRACT}

Aims: Fruits of a multivitamin culture of blackcurrant have a pronounced seasonality of consumption. The essence of the problem is in the scientific substantiation of the rational way of fruits freezing in order to preserve their quality.

Place and Duration of Study: The research was conducted during four years in the conditions of the laboratory of the Department of Technology of Storage and Processing of Plant Products at Uman National University of Horticulture and the workshop for rapid freezing of Uman canning plant.

Methodology: Prepared berries of the consumer degree of ripeness of Pilot Oleksandr Mamkin, Mynai Shmyriov, Novyna Prykarpattia, Biloruska solodka varieties in the string bags were frozen by slow $\left(-20\right.$ to $\left.-22^{\circ} \mathrm{C}\right)$ and rapid $\left(-30\right.$ to $\left.-32^{\circ} \mathrm{C}\right)$ methods, packed in paraffined boxes, polyethylene bags of $400-500 \mathrm{~g}$ by weight. Losses in fruit weight, content of ascorbic acid, dry soluble substances, sugars, acids, sugar-and-acid index were determined during and for 10 months of storage $\left(-18^{\circ} \mathrm{C}\right)$.

Results: True chemical composition of the fruits took into account losses of their weight. It radically changed the level of indicators. Weight losses of the fruits was lower by a third during fast freezing, however, the overall indicators did not differ significantly until the end of storage: $11.9-12.1 \%$ by slow method against $10.1-11.2 \%$ by rapid way. The highest losses in the fruits were during the first 3 months, during 4-5 months - their level was stabilized and somewhat increased to the end of storage. Advantages by fruits packing in polyethylene bags were as follows: losses were 6-7 times 
lower than by string bags and 4-5 times - in paraffined boxes. Advantages of rapid freezing were in 1.2-1.6 times lower losses of the components of chemical composition. Usually, the frozen fruits of Biloruska solodka variety were better than other varieties under favourable weather conditions, they were not inferior.

Keywords: Fruits; blackcurrant; freezing; storage; losses of weight; dry soluble substances; sugars; acids; ascorbic acid.

\section{INTRODUCTION}

There is an urgent task to organize protective nutrition, search for biologically valuable products of natural origin which can positively affect the population health under current environmental conditions in the field of nutrition [1].

The multivitamin culture of blackcurrant corresponds to this criterion, its fruits have high dietary and therapeutic properties, and there are no equal fruits and berries by the content of irreplaceable ascorbic acid and polyphenolic substances which the human body should regularly receive.

Blackcurrant contains dry soluble substances $11-22 \%$, including sugars $-5-14 \%$, acids $-1.5-$ $3 \%$, as well as pectinates - 1.5-2.5\%, polyphenols to $1 \%$ depending on the growing area and variety. However, blackcurrant is the largest source of ascorbic acid. Its content in the fruits varies considerably from $44-218 \mathrm{mg} / 100 \mathrm{~g}$ [2,3], 50-350 mg/100 g [4,5], according to other data it varied from 100-200 mg/100 g [6-8], $100-300 \mathrm{mg} / 100 \mathrm{~g}[9,10]$.

The level of ascorbic acid in the blackcurrant fruits is influenced by numerous factors: peculiarities of the variety, growing area, conditions of cultivation, age of the bush, branches, their location, size and part of the fruit, degree of its ripeness, and others [11]. A characteristic feature of blackcurrant is the reduction by 1.3-2.3 times of the ascorbic acid content by the end of fruit ripening and its higher level by less favourable weather conditions during the vegetation period $[9,12,13,14]$.

Accumulation of ascorbic acid in the blackcurrant fruits depends not only on the intensity of the synthesis, but also on the activity of enzymes. There is a reverse dependence between the content of ascorbic acid and the activity of ascorbic oxidase enzyme. The activity of the latter is non-significant or is not even displayed, while the activity of polyphenol oxidase is high which exhibits a stabilizing effect $[15,16]$.
Unfortunately, natural conditions cause a strongly seasonal consumption of healthful fruits of blackcurrant. It is possible to solve the problem of providing the population with the fruits throughout the year due to their sufficient production, long-term storage and preservation. However, biological characteristics and existing ways of storing the fresh fruits of blackcurrant limit the duration of their consumption $[8,11]$. The only way to improve the nutritional structure and ensure the priority way of nutrition is the use of modern canning methods. The essence of the problem is in the scientific substantiation of the rational way of fruits freezing in order to preserve biologically active substances in the fruits.

One of the most powerful and practical ways of storing the products is freezing. The high degree of preservation of the nutritional value and organoleptic properties of frozen fruits is based on the inhibition of biochemical processes and the life of the microflora. Microorganisms can develop at temperatures above -5 to $-8^{\circ} \mathrm{C}$, and yeast -10 to $-12^{\circ} \mathrm{C}$, mold fungi -12 to $-15^{\circ} \mathrm{C}$ [8].

Freezing is accompanied by a deep decrease in the fruits temperature and moisture transformation into ice, that is dehydration. Formation of ice crystals causes changes in the tissues structure of the product, the degree of which depends on the freezing speed $[8,11]$. Ice crystals are formed primarily in the intercellular spaces by slow fruits freezing at relatively high temperatures $\left(-4\right.$ to $\left.-8^{\circ} \mathrm{C}\right)$. Ice forms more slowly inside the cells where the concentration of juice is higher. Formation of ice crystals and associated increase in the concentration of juice in the intercellular spaces leads to the increase in osmotic pressure. Water from the cells passes into the intercellular space where it freezes on the sides of the previously formed crystals. In this case, the cells are dehydrated, and large crystals are formed in the intercellular spaces and unevenly spread in the tissues. They crush on the neibouring cells and cause damage of cell membranes and their death. Formed moisture does not have time to absorb, juice flows and product loses its natural properties: changes the 
consistency, becomes watery when fruits defrosting.

Rapid freezing (temperatures of -35 to $-40^{\circ} \mathrm{C}$ and below) does not cause significant deformation of the tissues structure. Speed of fruits cooling increases dramatically, ice crystals are formed simultaneously in the intercellular spaces and in the cells. Removal of moisture from the latter does not pass. The faster the process is performed, the more crystals are formed and their size is smaller. They are evenly spread in the cells and tissues, which does not cause significant damage to the cell membranes. More cells bind moisture and losses of cellular juice is not so significant when defrosting of these fruits.

Changes in the qualitative indicators of the fruits caused by the activity of enzymes and chemical reactions can take place before and after freezing. The intensity of the changes is influenced by a great number of factors connected with the technology of freezing, defrosting, species and varietal characteristics of the fruits. General conclusion concerning the fact that the frozen fruits are practically the same as the fresh ones by appearance, colour, flavour, taste, nutritional and biological value is a little exaggerated. This is not due to the physical-andchemical changes during freezing, which cause disorder in the tissues structure, but also the preservation of enzymatic activity. As a result, commodity state and taste properties of the product become worse, its vitamin value is significantly reduced. Unwanted losses of the components of the chemical composition occur mainly at the stage of defrosting of the frozen fruits $[8,11]$ since biochemical processes in the fruits are inhibited, but pass slowly and continuously under low storage temperatures.

The most labile indicator of the frozen fruits is the content of ascorbic acid. Its losses vary significantly depending on the temperature of freezing and fruit variety: $2-50 \%$ in strawberries, $4-45 \%$ in blackcurrant, $10-51 \%$ in gooseberry, $14-40 \%$ in grapes, and $48-72 \%$ until the end of storage. Increase in the content of ascorbic acid in strawberries is not excluded after freezing, but it is gradually reduced during storage. According to other data, preservation of ascorbic acid is 55$92 \%$ in frozen strawberries, depending on the method of pretreatment and $34-68 \%$ in $4-5$ months $[9,17]$.

High preservation of ascorbic acid is in the fruits of blackcurrant: $90-102 \%$ after freezing, and 89 $100 \%$ after 5-6 months of storage. Similar results were obtained after 8 months of fruits storage - 88-100\% [16] and 89-93\% [10]. However, preservation of vitamin $\mathrm{C}$ content in the frozen fruits can be reduced to $64-78 \%$ [9].

The aim of the research is to optimize the technology of blackcurrant freezing while preserving their quality. The following tasks are set to achieve the purpose - to conduct a comparative evaluation of slow and rapid freezing by changes in mass loss, chemical composition and ascorbic acid during storage in various types of packaging materials.

\section{MATERIALS AND METHODS}

The study was conducted during four years in the conditions of the laboratory of the Department of Technology of Storage and Processing of Plant Products at Uman National University of Horticulture and the workshop for rapid freezing of Uman canning plant.

Blackcurrant fruits of consumer degree of ripeness were gathered in favourable weather conditions, berries were taken into boxes-trays of $400-500 \mathrm{~g}$ by weight, transported to the laboratory and a rapid-freezing shop.

The fruits were packed in string packages with a capacity of $400-500 \mathrm{~g}$ (control) after inspection, washing, removal of water from the surface, re-inspection, then they were weighed, frozen by the following variants of the experiment:

-slow freezing in "Calex" freezing chambers at a -rapid freezing in a fast-freezing chamber with temperature of -20 to $-22^{\circ} \mathrm{C}$. forced circulation of air at a speed of 1.5-2.5 $\mathrm{m} / \mathrm{sec}$ under the temperature of -30 to $-32^{\circ} \mathrm{C}$.

The fruits of the experimental variants were packed in paraffin boxes and polyethylene bags weighing $400-500 \mathrm{~g}$ with film thickness of 50-55 $\mu \mathrm{m}$ after weighing and sealed.

Bags and boxes (experiment and control variant) were stored at temperatures not higher than $18^{\circ} \mathrm{C}$ up to 10 months. 


\begin{tabular}{|c|c|c|c|}
\hline \multicolumn{2}{|c|}{$\begin{array}{l}\text { Weight losses were determined in the } \\
\text { blackcurrant fruits of Pilot } O \text {. Mamkin variety } \\
\text { during freezing, and then after } 6,8 \text { and } 10 \\
\text { months of storage in string packages. } \\
\text { Repetition of the definition was ten times. }\end{array}$} & $\begin{array}{l}\text { Weight losses } \\
\text { fruits of Mynai } \\
\text { Novyna Prykar } \\
\text { and then every } \\
10 \text { months). Re }\end{array}$ & $\begin{array}{l}\text { mined in blackcurrant } \\
\text { Biloruska solodka, } \\
\text { ties during freezing, } \\
\text { er } 1,2,3,4,5,6,8 \text { and } \\
\text { was tenfold. }\end{array}$ \\
\hline \multicolumn{4}{|c|}{$\begin{array}{l}\text { The components of the chemical composition of the frozen fruits (were determined in specified } \\
\text { terms): }\end{array}$} \\
\hline $\begin{array}{l}\text { Content of } \\
\text { ascorbic acid }\end{array}$ & $\begin{array}{l}\text { Dry soluble } \\
\text { substances }\end{array}$ & Acids & $\begin{array}{l}\text { Sugar-and-acid index } \\
\text { was calculated }\end{array}$ \\
\hline
\end{tabular}

Determination of the components content of the chemical composition of the fruits, taking into account weight losses, was carried out according to the formula:

$$
X=\frac{A \times(100-8)}{100},
$$

$X$ - the content of substances taking into account weight losses, \%; $A$ - the content of substances at the end of storage, \%; 8 - weight losses during storage period, $\%$.

In the course of the research, we determined: weight losses of the fruits - by weighing, the content of ascorbic acid - by iodometric (according to B. P. Pleshkov [18]), dry soluble substances - by refractometric, acids - by titrimetric, sugars - by ferricyanidine methods [17].

Content of dry soluble substances was determined by a refractometric method. The essence of the method was to determine the mass fraction of dry substances (DSS) in the product by the refractive index of its solution. Refractometer RPL-3M was used for determining. Two drops of black current juice or jelly applied on the prism of the refractometer, holding them for 5 minutes. The eyepiece was moved to connect the visor with the boundary of dark and light fields and the percentage of dry soluble substances was determined by a scale.

Content of titrated acids of black current juice and jelly was defined by titration of water extract of weight with alkali solution of certain normality. Weight of $5 \mathrm{~g}$ was weighed to the nearest \pm 0.01 $\mathrm{g}$, placed in a glass and dissolved with distilled water in a volume of $100 \mathrm{~cm}^{3}$. 3-4 drops of phenolphthalein solution were added and it was titrated with $0.1 \mathrm{n}$ solution of sodium hydroxide $(\mathrm{NaOH})$ until appearing of a pink colour which did not disappear within a minute.
Acidity was calculated by the formula:

$X=2 \times V \times K$

where $X$ - acidity, \%;

$V$-amount of $0.1 \mathrm{n}$ solution of sodium hydroxide used for titration, $\mathrm{cm}^{3}$;

$K$ - correction factor of the solution of sodium hydroxide used for titration.

Content of sugars was determined by a ferricyanide method which was based on oxidation of reducing sugars with an alkaline solution of potassium ferricyanide $\left(\mathrm{K}_{3}\left[\mathrm{Fe}(\mathrm{CN})_{6}\right]\right.$. Sample weight $(\mathrm{m}, \mathrm{g})$ was calculated by the formula:

$S_{n}=0.2 \times V / a$

where $V$ - volume of a volumetric flask, $\mathrm{cm}^{3}$; $a-$ possible sugar content in studied product, $\%$.

Weight was weighted in a glass, put it in a measuring flask of $200 \mathrm{~cm}^{3}$, filled with distilled water to half of the capacity. The flask with weigh was kept in water bath with the temperature of $60^{\circ} \mathrm{C}$ for 15 minutes. Then it was cooled to the temperature of $20^{\circ} \mathrm{C}$ and precipitated nonsugar matters by successively adding of $10 \mathrm{~cm}^{3}$ of sulfuric acid zinc $\left(\mathrm{ZnSO}_{4}\right)$ and sodium hydroxide $(\mathrm{NaOH})$ at concentrations of $1 \mathrm{~mol} / \mathrm{dm}^{3}$. Contain of the flask was brought to the mark, mixed and filtered.

$25 \mathrm{~cm}^{3}$ of alkaline solution of potassium ferricyanide $\left(\mathrm{K}_{3}\left[\mathrm{Fe}(\mathrm{CN})_{6}\right], 8 \mathrm{~cm}^{3}\right.$ of experimental solution and $2 \mathrm{~cm}^{3}$ of distilled water was put into a conical flask of $250 \mathrm{~cm}^{3}$. Solution in the flask was heated to boiling on a cooker, kept at this temperature for 1 minute, then cooled, filled the cuvette $(5 \mathrm{~mm})$ and colourimetried with a wavelength of $400-440 \mathrm{~nm}$ (blue colour filter). The number of reducing sugars in $\mathrm{X}, \%$ was calculated by the formula:

$X=a \times V / 10 \times C \times m \times K$ 
where a - number of invert sugar calculated by calibration curve, mg;

$V$ - volume of the flask where weight was dissolved, $\mathrm{cm}^{3}$;

C - volume of studied solution for colorimetric determination, $\mathrm{cm}^{3}$;

$m$ - sample weight, g;

$K$ - correction factor took into account the oxidation of sucrose contained in the volume under study.

$50 \mathrm{~cm}^{3}$ of filtrate was transferred to the volumetric flask of $100 \mathrm{~cm}^{3}, 3 \mathrm{~cm}^{3}$ of concentrated hydrochloric acid $(\mathrm{HCl})$ was added, immersed it in a thermometer flask and placed on a water bath heated to $60^{\circ} \mathrm{C}$ to determine the total amount of sugar. In 2-3 minutes the temperature of the solution in the flask was increased to $67-70^{\circ} \mathrm{C}$ and kept at this temperature for 5 minutes. The solution was quickly cooled to the temperature of $20^{\circ} \mathrm{C}$. The solution of invert sugar was neutralized with sodium hydroxide $(\mathrm{NaOH})$, one drop of methylorange was added and it was brought to the mark.

Amount of reducing sugars after inversion was determined in the same way as before inversion. Content of total sugar, which was defined in the invert one, was calculated by the formula:

$$
X_{1}=\frac{a^{*} V}{5 * m^{*} C}
$$

where $X_{1}$ - amount of total sugar in terms of inversion, \%;

$V$ - volume of the volumetric flask where weight was dissolved, $\mathrm{cm}^{3}$;

a - number of reducing sugars found by calibration curve, mg;

$m$ - weight, g;
C- volume of solution for calorimetry, $\mathrm{cm}^{3}$.

Content of sucrose S (\%) was calculated by the formula:

$$
S_{n}=0.95 *(X 1-X)
$$

Sugar acid index: The sensation of sweet and sour taste depends on the ratio of sugar and acid in fruits (sugar acid index), it is expressed in relative units obtained by dividing the percentage of the mass part of sugars by the percentage of mass part of the acids.

Repetition of chemical analyzes is threefold. Weight of the sample for analysis is $2 \mathrm{~kg}$.

Statistical processing of research results was carried out using dispersion and correlation analyzes using special software packages (Excel, Statistika) $[16,17,19]$.

\section{RESULTS AND DISCUSSION}

The dynamics of the main components of the chemical composition of frozen blackcurrant fruits was studied. However, received results did not reveal the true regularity in the changes. Recalculation of the data taking into account weight losses of the fruits during freezing and storage was done for this reason. According to data (Table 1), weight losses of the fruits were 1.2$1.6 \%$ during freezing. Specified process was logical. Partially free moisture in the fruits and water which always remains on the surface of the fruits and the walls of the package evaporates under low temperatures and low relative humidity of the air. The area of evaporation increases because of small size of blackcurrant fruits. Circulation of the air in the chamber facilitated it.

Table 1. Weight losses of frozen blackcurrant fruits of Pilot 0 . Mamkin variety (packaging method - string bags), \%

\begin{tabular}{llll}
\hline Method of freezing & Storage time & \multicolumn{2}{c}{ The fruits are grown in weather conditions } \\
\cline { 3 - 4 } & & Unfavourable & Favourable \\
\hline Fast freezing & During freezing & 1.25 & 1.16 \\
& For 6 months of storage & 8.63 & 7.65 \\
& For 8 months of storage & 9.75 & 8.53 \\
& For 10 months of storage & 11.2 & 10.11 \\
\multirow{3}{*}{ Slow freezing } & During freezing & 1.57 & 1.41 \\
& For 6 months of storage & 8.51 & 7.83 \\
& For 8 months of storage & 9.92 & 9.44 \\
& For 10 months of storage & 12.13 & 11.85 \\
\hline$L S D_{05}$ & & \multicolumn{3}{c}{0.82} \\
\hline
\end{tabular}


Weight losses significantly increased under longtime storage of the frozen fruits due to the phenomenon of sublimation. They reached 10.1$12.1 \%$ depending on the method of freezing by the end of storage. However, distribution of weight losses during 10 months of storage was uneven. They were $6.5-7.4 \%$ under rapid and $6.4-6.9 \%$ under slow freezing during 6 months, which corresponded to 65 and $56 \%$ of total losses. During the next 2 months ( 8 months of storage), the fruits lost $0.9-1.1 \%$ under rapid and $1.4-1.6 \%$ under slow freezing, resulting in a total loss of $9.3 \%$ and $12.6 \%$ respectively. Fruit storage at the final stage from 8 to 10 months increased weight losses by 1.5-1.6\% under rapid and by $2.2-2.4 \%$ under slow freezing. This increased the percentage of losses by 14.3$21.7 \%$, respectively from the total losses.

Received results indicate that the highest weight losses during frozen fruits storage were at the beginning of storage, then their size decreased (stabilized), and they again increased somewhat until the end of storage. This was confirmed by the data of monthly weight losses of the fruits. Calculations showed that losses were 1.1-1.2\% monthly for 6 months of storage irrespective of the freezing method. They were $0.5-0.6 \%$ under rapid and $0.7-0.8 \%$ under slow freezing in the period of storage from 6 to 8 months. Weight losses increased every month and were $0.7-$ $0.8 \%$ under rapid and $1.1-1.2 \%$ under slow freezing at the storage period from 8 to 10 months.

Weight losses of the frozen fruits during storage indicated at their monthly increase regardless of the type of packaging, variety, year of research. However, there were certain patterns in weight losses. Absolute weight losses of the fruits decreased every next month of storage, but their level increased, adding data of the previous months. The highest weight losses in the fruits were observed in the first three months of storage. They were $0.036-0.045 \%$ in string bags, $0.026-0.035 \%$ in paraffined boxes for one day. During the 4-5 month storage, there was a tendency to reducing the losses and keeping them at the level of 1 day: string bags - 0.029$0.036 \%$, paraffin boxes $-0.020-0.025 \%$.

The level of weight losses of the frozen fruit was almost stabilized after 5-month storage and remained unchanged until the end of storage. Namely: $0.028-0.031 \%$ in string bags, 0.019 $0.021 \%$ in paraffined boxes.

The data of weight losses of the frozen fruits in polyethylene bags were different from the previous ones. They were $0.30-0.42 \%$ during the entire period of storage. And although weight losses were very low, the order of their formation remained during 10 months of storage. The products had the highest losses - 0.0014$0.0023 \%$ per day preferably to 3 months of storage. The level of losses decreased and was $0.0011-0.0014 \%$ during $4-5$ months of storage. Their level was somewhat higher of $0.0016-$ $0.0018 \%$ only in the fruits of Biloruska solodka variety. After 6 months of storage, weight losses of the fruits were stable and in the range of $0.0010-0.0011 \%$, and $0.0014-0.0016 \%$ in the fruits of Biloruska solodka variety.

Unconditional advantages of polyethylene packaging were established. The total weight losses of the frozen fruits in polyethylene bags was lower compared to string bags, on average in 5.7-7.0 times. There was a slightly smaller difference between the variants of polyethylene packaging and paraffined boxes - in 4-4.8 times.

Packing of the frozen fruits in paraffined boxes helped to reduce weight losses of the fruits by 1.4 times. However, they were considerably inferior to polyethylene bags because of the lack of sealing.

Taking into account the above-mentioned data on weight losses of the frozen fruits, the situation concerning their qualitative composition radically changed. Absolute values of the components of the chemical composition of the fruits decreased, hence the relative losses increased. In fact, losses of dry soluble substances, sugars, ascorbic acid during freezing and storage were 1.2 times higher. Increase in the acid content which was observed during the storage period of the frozen fruit was 1.2-1.3 times lower.

The duration of storage particularly influenced the indicators of the chemical composition. It would be a mistake to assume that the content of dry soluble substances and sugars increased by $1.0-1.7 \%$ during 6 months of storage of the frozen fruits. Recalculation showed a reverse, the latter decreased by $7-10 \%$. There was the same during 8 and 10 months of storage. Formed appearance of increasing the content of sugars during storage was not actually true. It was obvious that the data presented in the scientific articles were so different and sometimes had opposite tendencies because not all authors took into account weight losses and studied changes in the chemical composition of the fruits in dynamics, and presented distorted data. 
Osokina et al.; ARRB, 35(10): 97-112, 2020; Article no.ARRB.61468

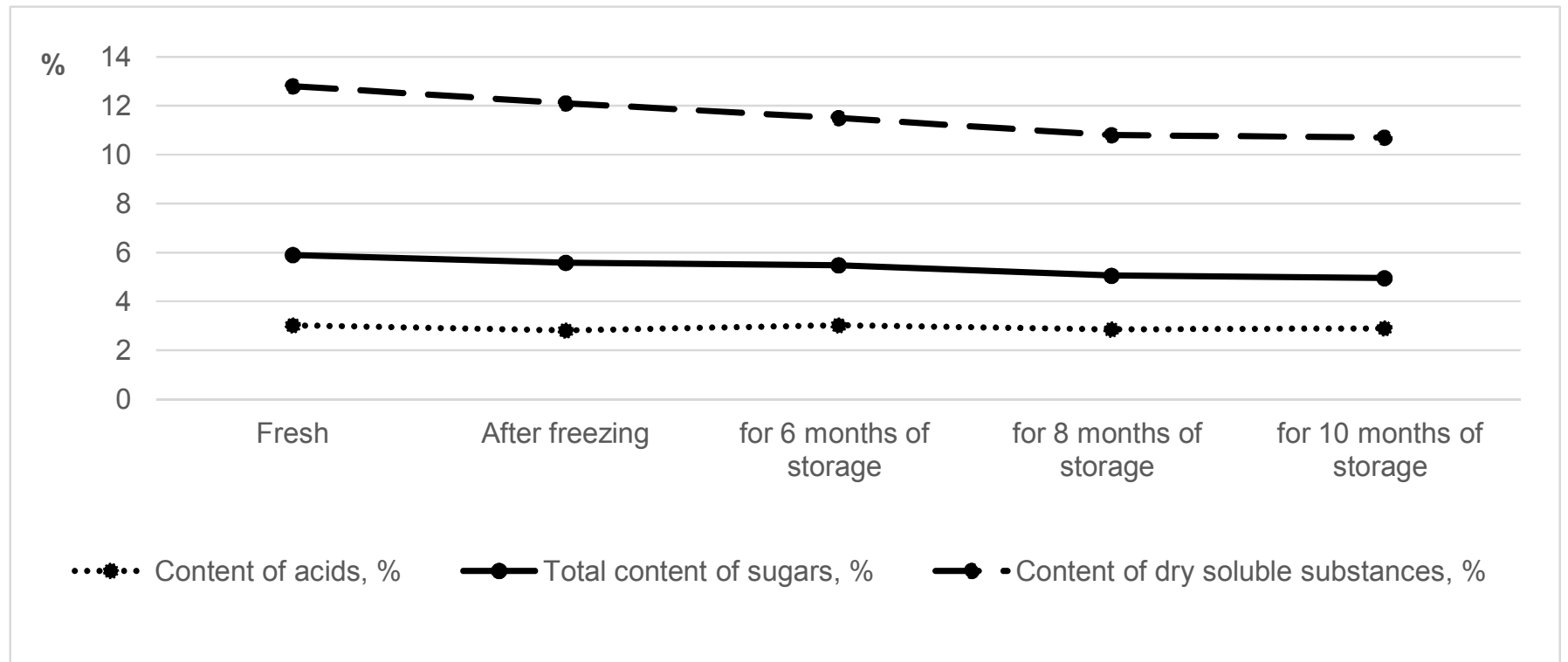

Fig. 1. Indicators of chemical composition (taking into account weight losses) of blackcurrant fruits of Pilot O. Mamkin variety (packing method mesh bags) - Fast freezing 
Osokina et al.; ARRB, 35(10): 97-112, 2020; Article no.ARRB.61468

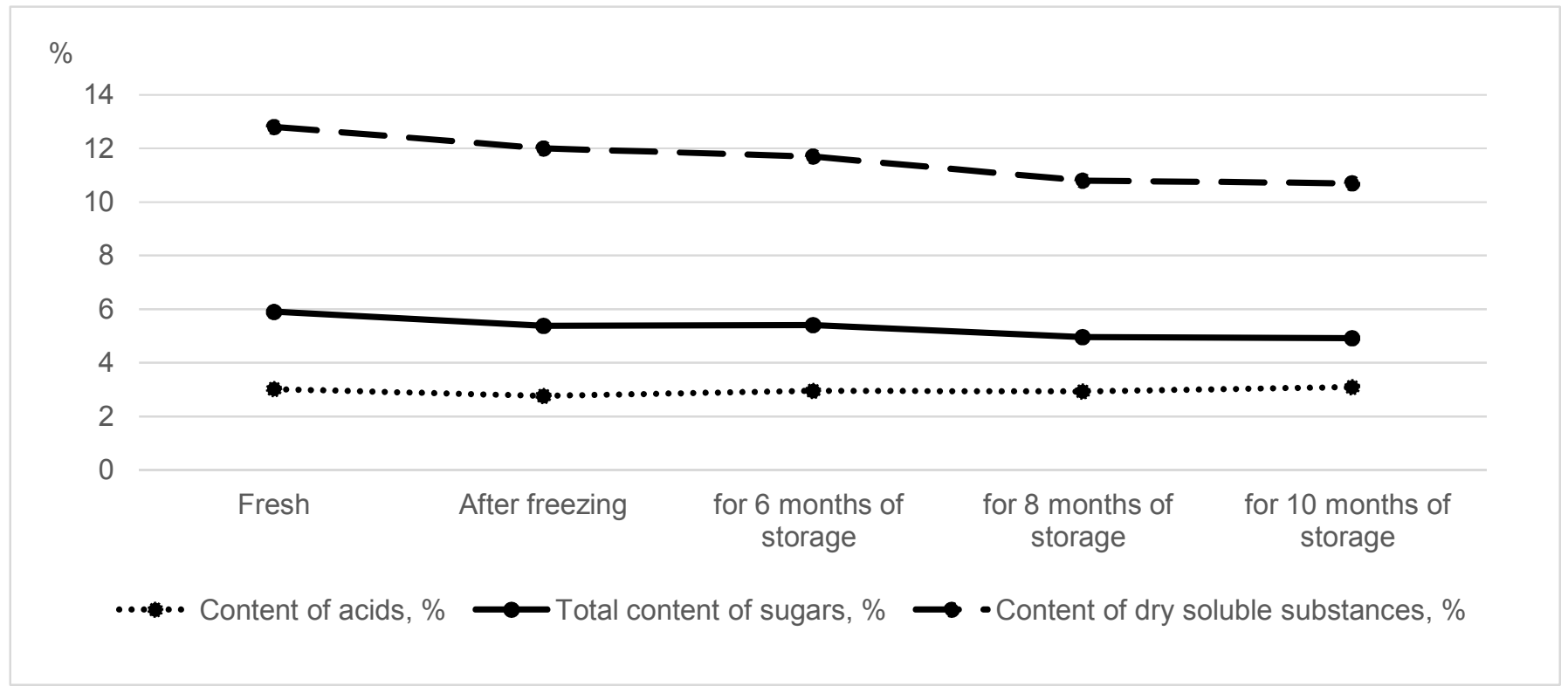

Fig. 2. Indicators of chemical composition (taking into account weight losses) of blackcurrant fruits of Pilot O. Mamkin variety (packing method mesh bags) - Slow freezing 
According to Figs. 1 and 2, the content of components of the chemical composition in frozen fruits is lower (except for acids) than fresh ones. Significant changes in the chemical composition of the frozen fruits occurred during freezing. And freezing speed influenced greatly the level of indicators. The content of dry soluble substances decreased compared with fresh fruits by $5.2-5.9 \%$ under rapid and by $5.5-6.3 \%$ under slow freezing, the content of sugars was 4.9$5.4 \%$ and $6.0-8.6 \%$, respectively; acid content by $7.0-9.6 \%$ and $8.6-10.4 \%$, respectively. While, a decrease in the content of dry soluble substances was $10-11 \%$, sugars - $2-10 \%$ regardless of the freezing method during 10 months of storage. The acidity of the fruits increased during storage and exceeded it in fresh fruits by $7.0 \%$ under rapid and $2.3-3.1 \%$ under slow freezing.

Consequently, a significant decrease in the content of dry soluble substances and sugars occurred at the freezing stage and was 53-63\% and $47-52 \%$, respectively, of the total reduction in substance content for 10 months of storage. This indicated that the frozen fruits did not remain stable in the content of dry soluble substances, including sugars during storage. Reduction in the content of dry soluble substances was $7.8-10.1 \%$ for 6 months of storage, $12.3-15.5 \%$ for 8 months and $15.1-$ $16.7 \%$ for 10 months of storage in the fruits after freezing. Losses of sugars in the frozen fruits during storage were smaller but significant. Reduction was $6.0-8.3 \%$ for 6 months, $7.2-$ $15.9 \%$ for 8 months and $7.9-16.9 \%$ for 10 months.

The dynamics of acids in the frozen fruits represented interest. As already noted, the acidity of the fruits decreased at the stage of freezing. But a progressive increase in acid content of fruit was observed during 10 months of storage. This was especially evident when comparing data with the content of acids in the freshly frozen fruits. Their number increased by $6.0-7.8 \%$ for 6 months of storage, by $5.8-11 \%$ for 8 months, by $5.8-15.9 \%$ for 10 months of storage. On average, the frozen fruits for 10 months of storage had 1.2 times higher acid content than in the fruits immediately after freezing. However, the acidity of the frozen fruits was within the range of fresh ones or grew by $0.07-0.19 \%$, and it was $2.3-7.0 \%$.
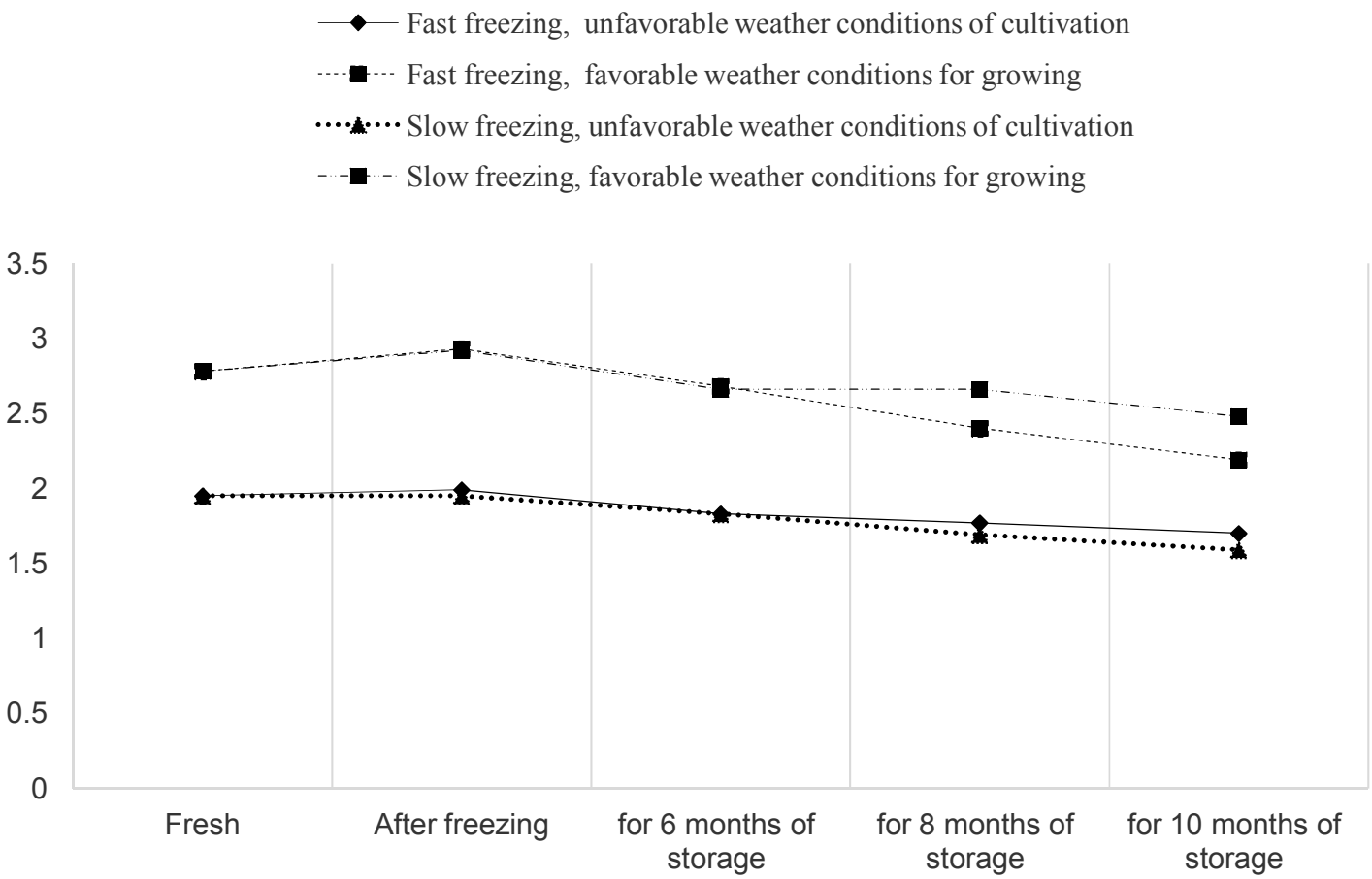

Sugar acid index

Fig. 3. Sugar acid index of blackcurrant fruits of Pilot $O$. Mamkin variety (packing method mesh bags) 
The objective indicator of the fruits state was sugar-and-acid index (Fig. 3).

The level of sugar-and-acid index significantly depended on the weather conditions of the vegetative period. A tangible increase in the index level - for fruits of Pilot $O$. Mamkin variety in 1.4 times was under favourable conditions for the synthesis of sugars. It remained unchanged or slightly increased during freezing. A tendency towards a gradual decrease in the level of the indicator was observed when storing of the frozen fruits, but only by $0.1-0.3$ units, which was $3-10 \%$ of the fresh fruits. But the level of the indicator dropped in 1.2 times for 10 months of storage - the fruits became even sourer.

Fruit freshness, taste and appearance are confirmed by the correlation (Figs. 4-6) between quality indicators. A direct strong relationship was established between the content of dry soluble substances and sugars $(r=0.94)$ and the inverse average between the content of dry soluble substances and acids and the content of sugars and acids $(r=0.70)$. The sugar-acid index directly and strongly correlated with the content of dry soluble substances $(r=0.88)$, sugars $(r=$ $0.95)$, and cautiously with the content of acids $(r=0.91)$.

A tendency to decrease its level in the frozen fruits was established in the dynamics of ascorbic acid (Fig. 7). Moreover, a sharp decline of vitamin $\mathrm{C}$ content was found at the stage of fruits freezing. Its quantity decreased by $15-21 \%$ in rapidly frozen and $22-24 \%$ in slow frozen fruits.

Losses of ascorbic acid in the fruits increased significantly when increasing the duration of storage. Its quantity in fruits decreased by $27-$ $29 \%$ under rapid and by $30-37 \%$ under slow freezing for 6 months; by $33-36$ and $43-48 \%$, respectively, for 8 months; by $38 \%$ and $51-52 \%$, respectively, for 10 months. That is, $39-55 \%$ of all losses of ascorbic acid in the fruits occurred during freezing.

Conducted analysis confirmed the benefits of rapid freezing for preserving the chemical composition of the fruits. Losses of these components were lower in 1.2-1.6 times during freezing by this time. The benefits were not always significant when stored, but the tendency remained well expressed, especially by the content of ascorbic acid. The level of the latter in the rapidly frozen fruits was 1.3 times higher.

Monthly decrease or increase in the level of indicators under research compared with fresh fruits and after freezing were calculated to determine the tendencies in the changes of the chemical composition of the frozen blackcurrant fruits.
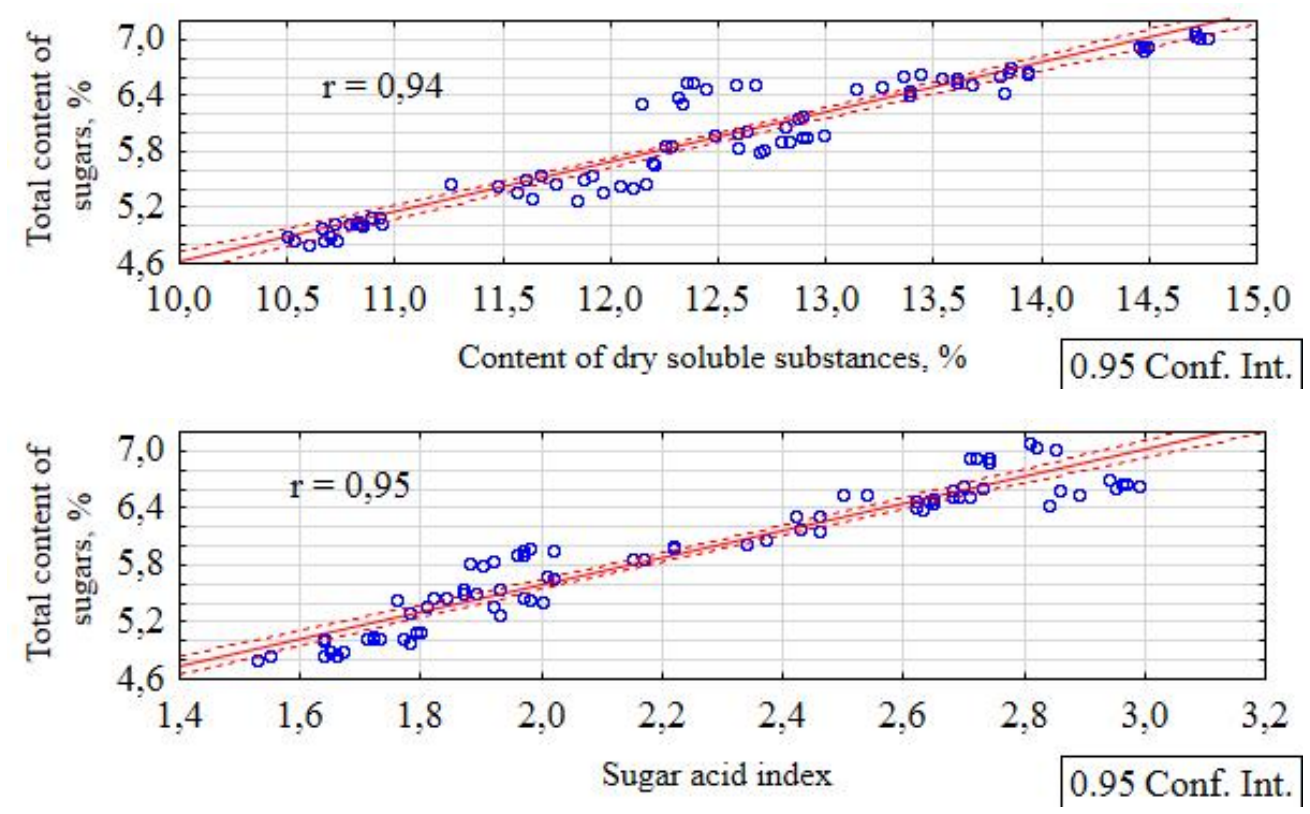

Fig. 4. Correlation between total sugar content and dry soluble substances content and sugaracid index 

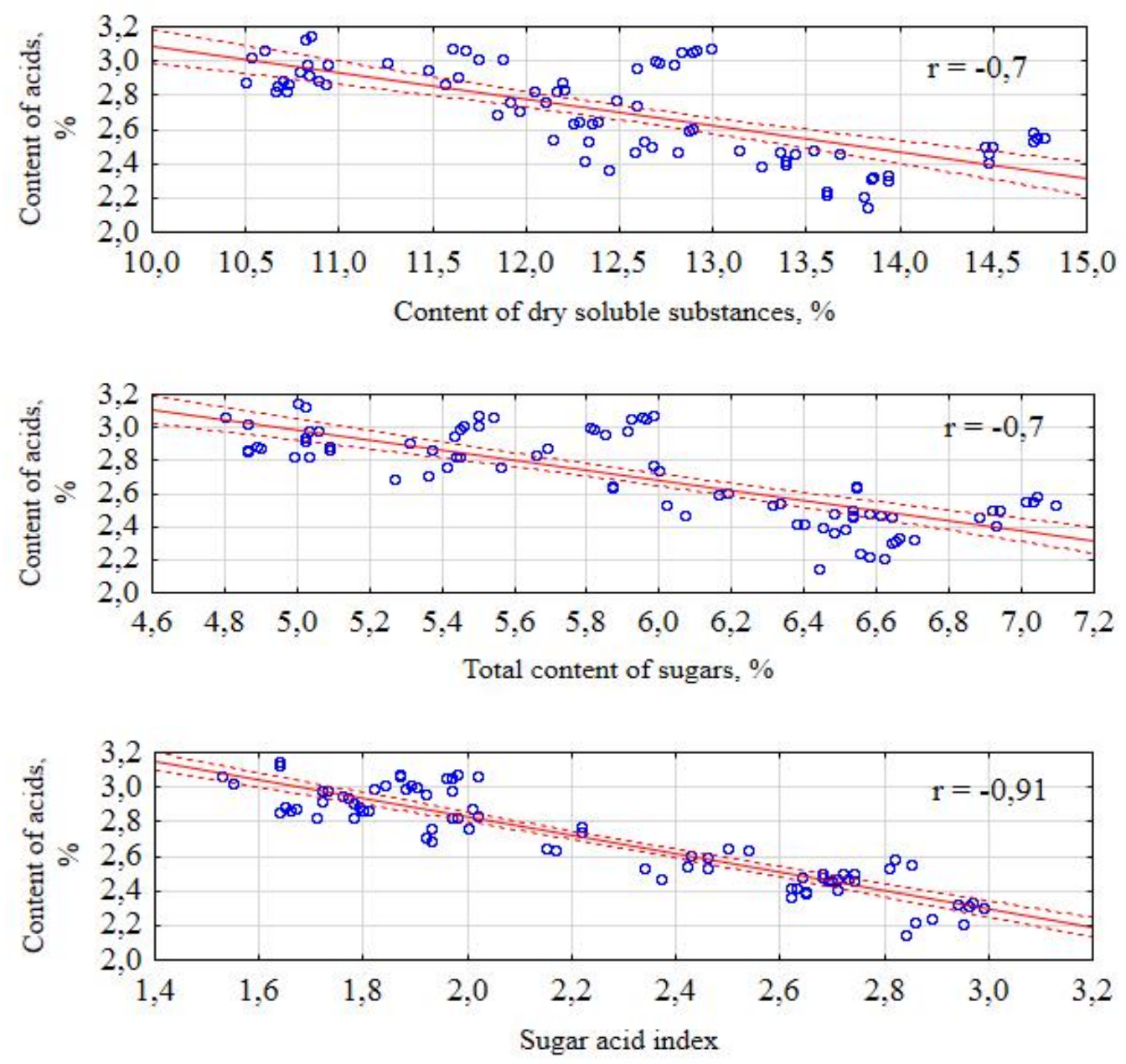

Fig. 5. Correlation dependence between the content of acids and the content of dry soluble substances, sugar and sugar-acid index

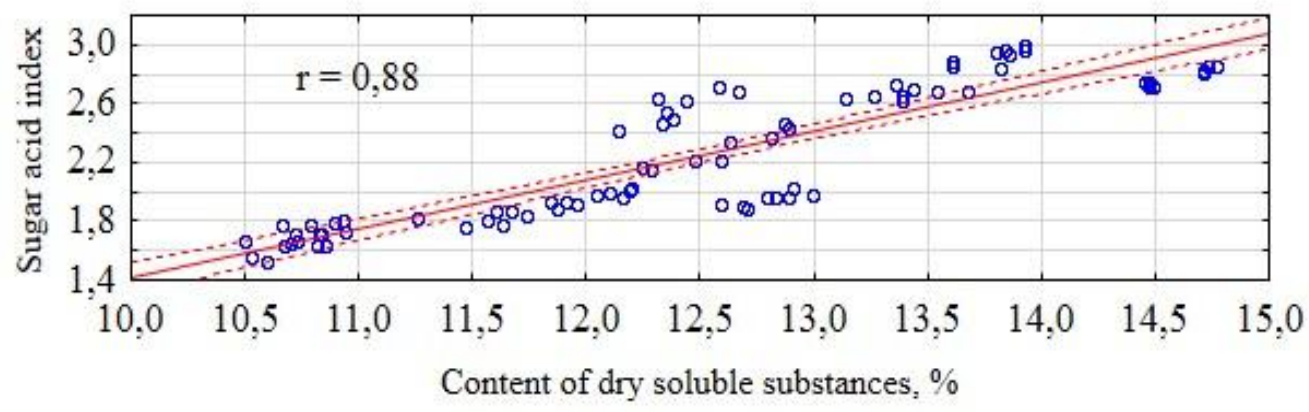

Fig. 6. Correlation dependence between sugar-acid index and the content of dry soluble substances

Data in the Table 2 shows monthly decrease in the content of dry soluble substances in the frozen fruits during storage was most pronounced up to 8 months. Monthly losses decreased or remained at the previous level, both in comparison with the fresh and frozen fruits under subsequent storage up to 10 months. 


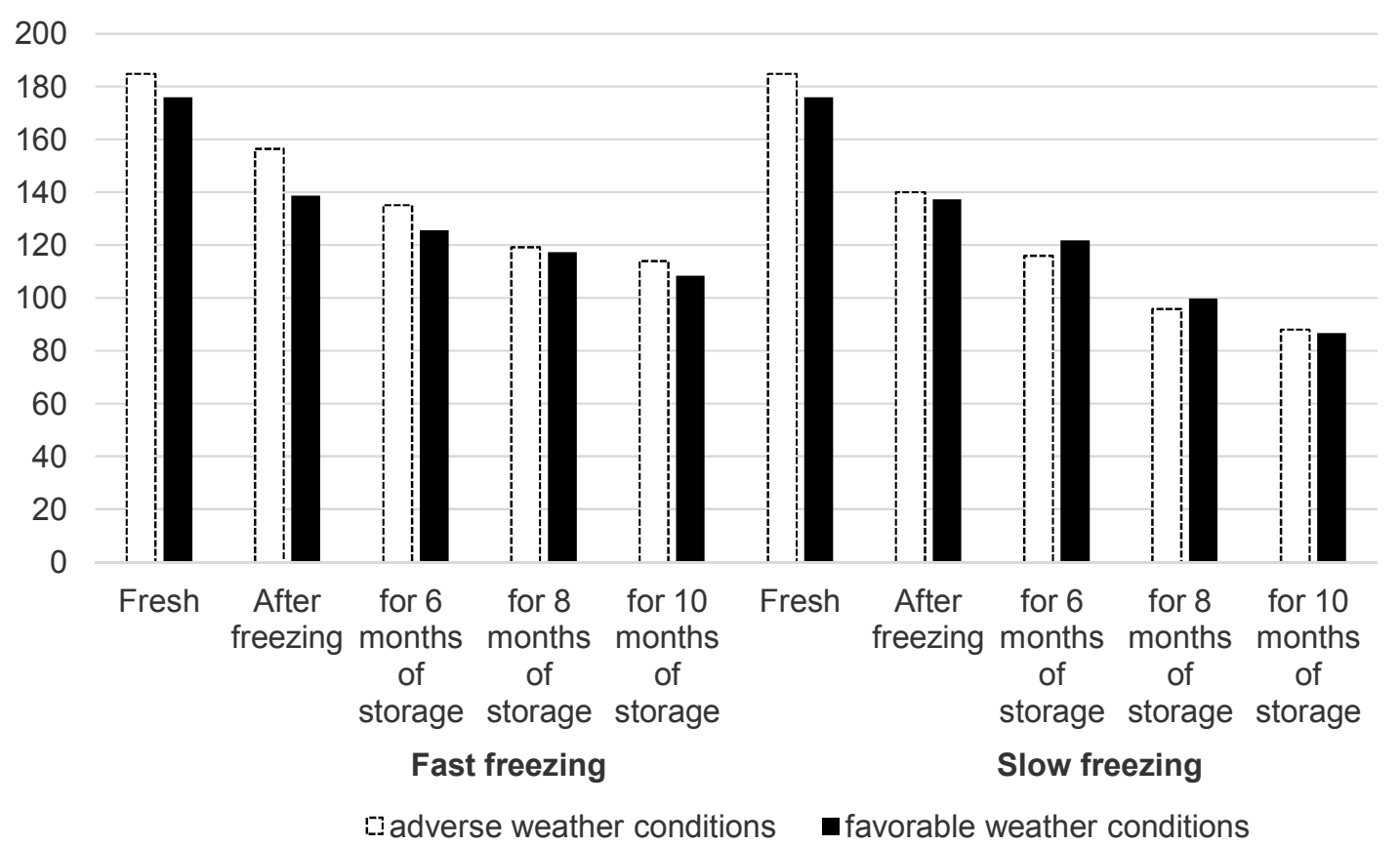

Fig. 7. The dynamics of the content of ascorbic acid (taking into account weight losses) of blackcurrant fruits of Pilot $\mathrm{O}$. Mamkin variety depending on the duration of storage (packing method - mesh bags), $\mathrm{mg} / 100 \mathrm{~g}$

Table 2. Monthly decrease (+ increase) in the content of the components of the chemical composition of the frozen blackcurrant fruits of Pilot $\mathrm{O}$. Mamkin variety (taking into account weight losses)

\begin{tabular}{|c|c|c|c|c|c|c|c|c|}
\hline \multirow[t]{3}{*}{ Fruits } & \multicolumn{2}{|c|}{$\begin{array}{c}\text { Content of dry } \\
\text { soluble } \\
\text { substances, \% }\end{array}$} & \multicolumn{2}{|c|}{$\begin{array}{l}\text { Total content } \\
\text { of sugars, \% }\end{array}$} & \multicolumn{2}{|c|}{$\begin{array}{l}\text { Content of } \\
\text { acids }^{1}, \%\end{array}$} & \multicolumn{2}{|c|}{$\begin{array}{c}\text { Content of } \\
\text { ascorbic acid, } \\
\mathrm{mg} / 100 \mathrm{~g}\end{array}$} \\
\hline & \multicolumn{8}{|c|}{ Fruits grown under weather conditions ${ }^{3}$} \\
\hline & - & + & - & + & - & + & - & + \\
\hline \multicolumn{9}{|c|}{ Rapid freezing } \\
\hline Fresh & 12.8 & 14.6 & 5.90 & 6.98 & 3.02 & 2.51 & 184.8 & 176.0 \\
\hline After freezing & 0.75 & 0.76 & 0.32 & 0.34 & 0.21 & 0.24 & 28.4 & 37.3 \\
\hline \multirow[t]{2}{*}{ For 6 months of storage } & $0.22^{21}$ & 0.22 & 0.07 & 0.07 & 0.01 & 0.01 & 8.3 & 8.4 \\
\hline & 0.09 & $\overline{0.09}$ & $\overline{0.02}$ & $\overline{0.01}$ & $\overline{+0.03}$ & $\overline{+0.03}$ & $\overline{3.6}$ & $\overline{2.2}$ \\
\hline \multirow{2}{*}{ For 8 months of storage } & 0.25 & $\underline{0.22}$ & $\underline{0.11}$ & $\underline{0.11}$ & $\underline{0.02}$ & +0.01 & $\underline{8.2}$ & $\underline{7.3}$ \\
\hline & 0.15 & 0.13 & 0.07 & 0.07 & +0.01 & $\overline{+0.04}$ & $\overline{4.7}$ & $\overline{2.7}$ \\
\hline \multirow[t]{2}{*}{ For 10 months of storage } & $\underline{0.21}$ & $\underline{0.22}$ & $\underline{0.09}$ & $\underline{0.11}$ & $\underline{0.01}$ & +0.02 & $\underline{7.1}$ & $\underline{6.8}$ \\
\hline & 0.14 & $\overline{0.14}$ & 0.06 & 0.07 & $\overline{+0.01}$ & $\overline{+0.04}$ & $\overline{4.2}$ & $\overline{3.0}$ \\
\hline \multicolumn{9}{|c|}{ Slow freezing } \\
\hline Fresh & 12.8 & 14.6 & 5.90 & 6.98 & 3.02 & 2.51 & 184.8 & 176.0 \\
\hline After freezing & 0.80 & 0.80 & 0.51 & 0.42 & 0.23 & 0.26 & 44.7 & 38.5 \\
\hline \multirow{2}{*}{ For 6 months of storage } & 0.18 & 0.19 & 0.08 & 0.06 & 0.01 & 0.01 & 11.5 & 9.0 \\
\hline & $\frac{0.05}{0.05}$ & 0.06 & $\frac{.003}{+0.03}$ & $\frac{\overline{0.01}}{0.01}$ & $\frac{.0 .03}{+0.03}$ & $\frac{1.03}{+0.03}$ & 4.1 & $\frac{\pi .6}{2.6}$ \\
\hline \multirow[t]{2}{*}{ For 8 months of storage } & 0.25 & 0.26 & 0.12 & 0.06 & 0.01 & 0.01 & 11.1 & 9.5 \\
\hline & 0.15 & 0.16 & 0.05 & $\overline{0.01}$ & +0.02 & +0.03 & 5.5 & $\overline{4.7}$ \\
\hline \multirow{2}{*}{ For 10 months of storage } & 0.21 & 0.23 & 0.10 & 0.06 & +0.01 & +0.01 & $9, .7$ & 8.9 \\
\hline & 0.13 & 0.15 & 0.05 & 0.01 & +0.03 & +0.03 & $\frac{0,1}{5.2}$ & $\frac{0.0}{5.1}$ \\
\hline Pe (Partial eta-sguared) & \multicolumn{2}{|c|}{0.96} & \multicolumn{2}{|c|}{0.84} & \multicolumn{2}{|c|}{0.63} & \multicolumn{2}{|c|}{0.96} \\
\hline
\end{tabular}


Table 3. Chemical composition of the blackcurrant fruits (slow freezing, storage in polyethylene bags)

\begin{tabular}{|c|c|c|c|c|c|c|c|c|c|c|c|c|c|}
\hline \multirow[t]{4}{*}{ Indicator } & \multirow{2}{*}{\multicolumn{4}{|c|}{ Mynai Shmyrov variety }} & \multirow{2}{*}{\multicolumn{4}{|c|}{ Biloruska solodka variety }} & \multirow{2}{*}{\multicolumn{4}{|c|}{ Novyna Prykarpattia variety }} & \multirow[t]{4}{*}{$L S D_{05}$} \\
\hline & \multicolumn{5}{|c|}{ Fruits grown under weather conditions ${ }^{3}$} & & & & & & & & \\
\hline & \multicolumn{2}{|r|}{+} & \multicolumn{2}{|r|}{-} & \multicolumn{2}{|c|}{+} & \multicolumn{2}{|r|}{-} & \multicolumn{2}{|r|}{+} & \multicolumn{2}{|r|}{-} & \\
\hline & Fresh & Freezing & Fresh & Freezing & Fresh & Freezing & Fresh & Freezing & Fresh & Freezing & Fresh & Freezing & \\
\hline $\begin{array}{l}\text { Dry soluble } \\
\text { substances, \% }\end{array}$ & 14.8 & $\frac{15}{14.77^{2}}$ & 16.0 & $\frac{16.2}{15.97}$ & 16.0 & $\frac{16.4}{16.07}$ & 16.0 & $\frac{16.2}{15.93}$ & 15.0 & $\frac{15}{14.8}$ & 14.6 & $\frac{14.8}{14.61}$ & $\frac{0.10}{-}$ \\
\hline Sugars, $\%$ & 7.45 & $\frac{7.5}{7.38}$ & 7.26 & $\frac{7.32}{7.21}$ & 9.25 & $\frac{9.28}{9.09}$ & 8.82 & $\frac{8.89}{8.74}$ & 6.89 & $\frac{6.93}{6.84}$ & 7.91 & $\frac{8.01}{7.91}$ & $\underline{0.84}$ \\
\hline Acids $^{1}, \%$ & 2.78 & $\frac{2,96}{2,91}$ & 3.32 & $\frac{3.44}{3.39}$ & 2.59 & $\frac{2.75}{2.7}$ & 2.55 & $\frac{2.68}{2.64}$ & 3.05 & $\frac{3.18}{3.14}$ & 2.61 & $\frac{2.74}{2.71}$ & $\frac{0.09}{-}$ \\
\hline Sugar acid index & 2.68 & $\frac{2.53}{2.53}$ & 2.19 & $\frac{2.13}{2.12}$ & 3.57 & $\frac{3.37}{3.37}$ & 3.46 & $\frac{3.32}{3.31}$ & 2.26 & $\frac{2.18}{2.18}$ & 3.03 & $\frac{2.92}{2.92}$ & $\frac{0.10}{-}$ \\
\hline $\begin{array}{l}\text { Ascorbic acid, } \\
\mathrm{M} / 100 \mathrm{r}\end{array}$ & 109.1 & $\frac{88.2}{86.8}$ & 182.1 & $\frac{148.6}{146.1}$ & 167.2 & $\frac{128.7}{126.1}$ & 273.5 & $\frac{207.4}{204}$ & 118.8 & $\frac{97.8}{96.5}$ & 229.3 & $\frac{185.1}{182.7}$ & $\frac{9.68}{-}$ \\
\hline
\end{tabular}

Notes: ${ }^{1}$ acidity in terms of malic acid; ${ }^{2}$ under the line - the content during storage taking into account weight losses; ${ }^{3}+$ favourable; - unfavourable 
A similar tendency was observed with the content of sugars. Monthly content of sugars decreased compared with the fresh fruits; and what is more, losses of sugars were smaller with each subsequent period of storage. Comparing the content of sugars in the frozen fruits during storage with such fruits during freezing indicated: losses of sugars could increase every month, be approximately the same or decrease.

Changes in the content of sugars in the frozen fruits, of course, had their nature. Decrease in sugars content during freezing is explained by losses of monosaccharides for respiration, which was particularly intense in the process of freezing (as a corresponding reaction of a plant cell to lowering the temperature) and after defrosting, especially in the presence of damaged cells. Partial reduction of sugars content during storage occurred as a result of their spending for residual respiration and other processes. This correlated with a sharp decrease in the reduced sugars in the process of freezing.

Increasing in the content of sugars in the frozen fruits during storage should be found in the changes not only mobile, but also slow-moving and stationary carbohydrates. Moreover, the degree and nature of these changes depended on the variety, freezing temperature and duration of storage. It was possible that the hydrolysis of polysaccharides and release of sugars from complex compounds was a source of their insignificant increase in the frozen fruits of blackcurrant during storage.

Changes in the acidity of the fruits were quite characteristic and stable. Increase in the content of acids in the frozen fruits occurred in the 8th10 th months of storage and increased monthly by $0.01-0.02 \%$ when comparing the frozen fruits with fresh ones. There was a tendency towards a monthly progressive increase in the acid content in 1.3-1.5 times if we compared the acidity of the frozen fruits during storage with the acidity of the freshly frozen fruits.

Causes of a characteristic increase in the acids content of the fruits were apparently contained in destructive changes. Acid fell for oxidizing-andreducing processes the most in the process of freezing and storage. Decrease of the acids content during freezing was due to their inclusion as a substrate to the process of respiratory gas exchange. Increasing of the acids content in the storage of the frozen fruits was probably the result of enzymatic hydrolysis which occurred at the expense of easily-hydrolyzed polymer molecules which amount in the damaged tissues increased.

The dynamics of a significant decrease in ascorbic acid in the frozen fruits was observed. Comparing the content of ascorbic acid in the frozen fruits during storage with such in the fresh fruits was characterized by the following: its monthly losses decreased from 8 to $7 \mathrm{mg} / 100 \mathrm{~g}$ or from 12 to $9 \mathrm{mg} / 100 \mathrm{~g}$. But this tendency reflected only relative indicators. In fact, the amount of ascorbic acid was reduced by 3-5 $\mathrm{mg} / 100 \mathrm{~g}$ almost equally every month in the frozen fruits.

Causes of undesirable reduction of ascorbic acid in the fruits appeared while freezing. This was due to the low temperature which inhibited all biochemical processes, including enzymatic. But catalytic ability of enzymes was restored when defrosting. Oxidizing enzymes restored their activity faster than restorative ones. As a result, ascorbic acid was irreversibly oxidized. The way of reducing the $\mathrm{C}$-vitamin activity of the frozen fruits was established. Transformation of ascorbic acid came to its oxidation to dehydroascorbic acid, and then to the physiologically inert form of 2,3-diketogulonic acid.

Significant influence of the weather conditions of the vegetation period on components saving of the chemical composition of the fruits. If the content of dry soluble substances and sugars was higher in the fresh fruits then after fruits freezing the tendency to their smaller losses during storage was maintained.

The opposite tendency in relation to the content of acids and ascorbic acid was expressed: the content of acids including ascorbic acid was lower in the fresh fruits, but there were the greater losses of them during freezing. In addition, acids in the frozen fruits accumulated more intensively during storage.

The effect of freezing method on the content of dry soluble substances in fruits - 90\%, ascorbic acid $-44 \%$, sugars $-21 \%$, acids $-14 \%$.

The study of the suitability of blackcurrant fruits to freezing showed (Table 3 ) that the chemical composition of the frozen fruits changed. However, decrease or increase in the content of the individual components in the tested fruits was not always reliable. Acid suffered the greatest changes. Their content in the frozen fruits in comparison with the fresh ones increased by 
$2.1-4.5 \%$, which was reflected at the level of dry soluble substances. Since the content of sugars in the fruits did not change significantly, and the content of acids increased, the sugar-and-acid index decreased - by $2.7-5.6 \%$. It remained the highest in the frozen fruits of Biloruska solodka variety - 3.3-3.4. The peculiarities of the variety had greatest influence at the level of dry soluble substances, sugars, acids in the frozen fruits $66,66,46 \%$, respectively.

The content of ascorbic acid in the frozen fruits depending on the variety has decreased by 19 $24 \%$. Preservation of ascorbic acid in the frozen fruits of Novyna Prykarpattia and Mynai Shmyriov varieties was $80-81 \%$, while it was slightly lower $-75 \%$ in Biloruska solodka variety. Power of influence of the variety on the content of ascorbic acid was $28 \%$ in the frozen fruits, the process of freezing - $12 \%$, and weather conditions of growing $-60 \%$.

The regularity remained unchangeable - the variety of blackcurrant and conditions that influenced the formation of the biochemical composition were the main objective indicators for establishing of their suitability for freezing.

The fruits of Biloruska solodka variety were distinguished by the qualitative composition, taste properties, content of ascorbic acid. Noted less preservation of ascorbic acid in the frozen fruits of this variety correlated with a significant tendency of the fruits towards cracking $-42 \%$.

The chemical composition of the frozen fruits of Novyna Prykarpattia, Mynai Shmyriov and Pilot O. Mamkin varieties depended largely on the weather conditions of yield formation. They were not inferior to the fruits of Biloruska solodka variety under favourable weather conditions during the period of blackcurrant vegetation.

\section{CONCLUSION}

Qualitative indicators of the frozen blackcurrant fruits depended on the method of freezing, packaging, duration of storage, pomological variety and weather conditions of the vegetation period.

It was necessary to take into account weight losses of the fruits during freezing and storage in order to determine their true chemical composition. It radically changed the level of indicators.

On average, weight losses were 1.3 times lower under rapid method of freezing. Total weight losses were not significantly different at the end of storage: $11.9-12.1 \%$ under slow method versus $10.1-12.2 \%$ under rapid one. However, the fruits had the greatest losses during the first 3 months of storage, the level of losses stabilized during 4-5 months and somewhat increased until the end of storage. The advantages of packing of the frozen fruits in polyethylene packages were established. Total weight losses of the fruits for 10 months of storage was 6-7 times lower than in string bags and 4-5 times than in paraffined boxes.

The most significant changes in the chemical composition of the fruits occurred during freezing. Reduction in the content of dry soluble substances in the fruits was $53-63 \%$, sugars $47-52 \%$ of the total decrease for the entire period of storage. By the end of fruits storage, the amount of dry soluble substances and sugars in them decreased by $8-17 \%$ of the content in the fresh ones, and the acidity rose by $6-16 \%$ leading to a decrease of sugar-and-acid index in 1.2 times. The content of ascorbic acid in the fruits during freezing was reduced by $15-24 \%$, which was $39-55 \%$ of all losses. Monthly storage resulted in a reduction in its amount in the fruits by $3-5 \mathrm{mg} / 100 \mathrm{~g}$. Advantages of rapid freezing were justified by 1.2-1.6 times lower losses of the content of dry soluble substances, sugars, acids, ascorbic acid and preservation of the appearance of the fruits.

The frozen fruits of Biloruska solodka variety had benefits by the chemical composition, taste and content of ascorbic acid. The chemical composition of the frozen fruits of Novyna Prykarpattia, Mynai Shmyriov and Pilot $O$. Mamkin varieties largely depended on the weather conditions. Their quality was not inferior to Biloruska solodka variety under favourable weather conditions.

\section{ACKNOWLEDGEMENTS}

The study was conducted in the Department of Technology of storage and grain processing of Uman National University of Horticulture.

\section{COMPETING INTERESTS}

Authors have declared that no competing interests exist.

\section{REFERENCES}

1. Kostetska K, Osokina N, Gerasymchuk O, Nakloka V. Objective organoleptic, 
structural-and-mechanical parameters of vegetables depending on their degree of ripeness. Agronomy Research. 2019;17 (6):2286-2294. Scopus.

Available:https://doi.org/10.15159/AR.19.2 03

2. Brennan RM, Jorgensen $L$, Hackett $C$, Woodhead M, Gordon S, Russell J. The development of a genetic linkage map of blackcurrant (Ribes nigrum L.) and the identification of regions associated with key fruit quality and agronomic traits. Euphytica. 2008;161:19-34.

3. Buendía B, Allende A, Nicolás E, Alarcón JJ, Gil MI. Effect of regu-lated deficit irrigation and crop load on the antioxidant compounds of pea-ches. Journal of Agricultural and Food Chemistry. 2008;56: 3601-3608.

4. Badejo AA, Tanaka N, Esaka M. Analysis of GDP-D-mannose pyro-phosphorylase gene promoter from acerola (Malpighia glabra) and increase in ascorbate content of transgenic tobacco expressing the acerola gene. Plant and Cell Physiology. 2008;49:126-132.

5. Deineka VI, Grigoriev AM. Opredelenye antotsyanov metodom vыsokoeffektyvnoi zhydkostnoi khromohrafyy. Nekotorbe zakonomernosty uderzhyvanyia. Journal of Analytical Chemistry. 2004;59(3):305-309. Russian.

6. Bulley SM, Rassam M, Hoser D, Otto W, Schünemann $N$, Wright $M$, MacRae $E$, Gleave A, Laing W. Gene expression studies in kiwifruit and gene overexpression in Arabidopsis indicates that GDP-L-galactose gua-nyltransferase is a major control point of vitamin $\mathrm{C}$ biosynthesis. Journal of Experimental Botany. 2009;60:765-768.

7. Chirkov Yul. Agrometeorology. Leningrad: Hidrometeoizdat. 1986;293. Russian.

8. Orlova NYa. Konsystentsyia y vlahouderzhyvaiushchaia sposobnost zamorozhennыkh plodov. Food Industry. 1992;1:24-25. Russian.
9. Zhbanova EV. Variatyvnost khimicheskogo sostavu plodov chornoi smorodyny. Agrarian Russia. 2012;1:10-13. Poc.

10. Zhbanova EV, Zatsepina IV. Zavysymost urozhainosty y kachestva plodov chernoi smorodynы ot pohodnыkh uslovyi vehetatsyonnoho peryoda. AGRO XXI. 2012;4-6:37-39. Russian.

11. Mukailov MD, Huseynova BM. Vlyianye nyzkotemperaturnoi zamorozky na pyshchevuiu tsennost klubnyky y malynd. Production and Sale of Ice Cream and Quick-frozen Products. 2004;2:28-29. Russian.

12. Müller-Moulé P. 2008. Plant. Molecular Biology. 2008;68:31-41.

13. Finn RD, Tate J, Mistry J, Coggill PC, et al. The Pfam protein family database. Nucleic Acids Research Database Issue. 2008;36: 281-288.

14. Gawel R. Red wine astringency: A review. Australian Journal of Grape and Wine Research. 2008;4:74-95.

15. Saizhyly El, Konukochlu D, Papyla S, Aksai T. Vitamins E, C, TBC-active products and cholesterol in plasma of patients with colorectal tumors. Biochemistry. 2003;68(3):393-396.

16. Walker PG, Gordon SL, Brennan RM, Hancock RD. A high-through-put monolithic HPLC method for the rapid vitamin C phenotyping of berry fruit. Phytochemical Analysis. 2006;17:284290.

17. Tsarenko OM, Zlobin YuA, Skliar VG, Panchenko SM. Computer methods in agriculture and biology: Study guide. Sumy: "Universytetska Knyga"; 2000; 203.

18. Pleshkov VP. Praktycheskye zaniatyia po byokhymyy. M.: Kolos. 1976;254. Russian.

19. Borovikov VP, Borovikov IP. Statistica. Statystycheskyi analyz y obrabotka dannыkh $v$ srede Windows. M.: Filin.; 1997;608. Russian.

(c) 2020 Osokina et al.; This is an Open Access article distributed under the terms of the Creative Commons Attribution License (http://creativecommons.org/licenses/by/4.0), which permits unrestricted use, distribution, and reproduction in any medium, provided the original work is properly cited.

Peer-review history:

The peer review history for this paper can be accessed here: http://www.sdiarticle4.com/review-history/61468 